\title{
Helping Struggling Readers Comprehend Information Texts
}

This experimental study examined the effect of an instructional intervention that combined the use of information texts and instruction in reading strategies to improve the reading comprehension of struggling grade 5 students. Elementary (primary) school children are infrequently instructed in strategies for reading informational text with its genre specific text structure although this is an essential component of information literacy. Two grade 5 classes were pre- and post- tested for reading comprehension. One class received instruction in collaborative strategy instruction for reading informational text. The post-test revealed that students in the experimental class achieved significantly better comprehension scores than the control class. This study examined the effect of an instructional intervention that combined the use of information texts and instruction in reading strategies to improve the comprehension of struggling fifth grade readers.

\section{Comprehension}

Reading comprehension has been described as the "essence of reading" (Durkin, 1993). It is the end purpose of all reading instruction (Pressley, 2000). Readers derive meaning from text when they engage in intentional, problem-solving thinking during reading. Successful comprehension of texts is the result of the efficient use and integration of lower order, word-level processes such as, decoding and higher order processes such as schematic knowledge and self-regulation strategies (Pressley, 2000). As such, there can be multiple sources of children's comprehension difficulties.

Comprehension results from the interaction between the reader's prior knowledge and the information contained in a specific text (Harris \& Hodges, 1995; Moravcsik \& Kintsch.1993). In comprehending a text readers construct a mental representation that integrates the content with an interpretation of the significance of the relationships amongst them (van den Broek \& Kremer, 2000). The level of knowledge about a topic already held by the reader influences the ease with which they can comprehend a new text; more knowledge allowing the reader to make multiple connections between the text and the world (Ericsson \& Charness, 1994).

Vocabulary knowledge also influences reading comprehension (Beck, McKeown \& Kucan, 2002; Graves \& Watts-Taffe, 2002; Medo \& Ryder, 1993). Vocabulary knowledge at school entry predicts reading comprehension in grade eleven (Cunningham \& Stanovitch, 1997). As children progress through school the vocabulary load in texts increases, with more abstract and technical vocabulary appearing in place of the language of everyday interaction that dominated primary level texts. In the same manner as background knowledge, vocabulary acquisition is mainly built through the quantity and variety of materials read by the child (Nagy \& Scott, 2000). Direct instruetion in vocabulary can enhance vocabulary 
acquisition but this instruction must be extensive involving multiple exposures so that students can develop the connections between words and their definitions (Beck \& McKeown, 1991).

\section{Information text}

There is the growing recognition of a need to increase the use of informational text in the classroom. Trabasso (1994) states that ninety percent of the texts read by children in elementary school are narratives, as is the case in primary classrooms (Duke, 2000; Duke, Bennett-Armistead \& Roberts, 2003). The assumption that intermediate grade students are reading informational texts in content area classes is inaccurate. Armbruster, Anderson, Armstrong, Wise, Janisch \& Meyer (1991) found that little actual reading of content area textbooks or trade books occurred in science or social studies classes, most instruction was lecture or discussion with minimal reading of any type of text on the part of children. This general lack of exposure to informational texts in school hinders the students' acquisition of background knowledge and vocabulary which then limits their ability to comprehend other texts. In essence, a negative feedback cycle occurs.

More troubling is elementary teachers' view of informational text. Shymansky, Yore and Good (1991) found, in a national survey of teachers' views of science reading, that the majority believed that science text did not need a different structure from that of other textbooks and thought that science textbooks would be improved if they were written as narratives. Thus many children experience little opportunity to read informational text in school and lack instruction in how to read it.

This lack of informational text use in the classroom is compounded by the topics chosen for study in elementary schools; most are already familiar to children, such as family, pets, friends etc. (Hirsch, 2003; Walsh, 2003) thus doing little to increase children's knowledge base and vocabulary. Informational text about substantial topics is essential for building conceptual knowledge and acquiring an academic vocabulary of abstract and technical words.

The variety of text structures that are found in informational text presents a challenge for comprehension. In reading a narrative text a reader can rely upon her understanding of human interaction to track motives and events (Bruner, 1986). Bruner argues that the understanding of story is deeply embedded in human cognition. Information text presents greater challenges as it frequently deals with unfamiliar and often abstract concepts such as justice or gravity, what Bruner labelled 'the paradigmatic'.

Information text is generally read for a different purpose than narrative. Narrative text is usually read for pleasure and is responded to aesthetically (Rosenblatt, 1978). Whereas, informational text is read in order to acquire conceptual knowledge or for a practical application, most frequently evoking an efferent response in the reader. This usual transaction with a type of text does not preclude the reader from taking an aesthetic stance toward informational text or the efferent one toward narrative.

Narrative text is easier to read than informational text as the reader can rely upon story grammar to build a model of the text (Graesser, Golding \& Long, 1991). Informational text requires the reader to integrate details to formulate the main idea. Text structure, the manner in which the ideas are organised within a text provides a map for the reader to build a 
model of the text. Learning the key signal words whereby an author indicates the text structure and instruction in the selection of graphic organisers that map onto different text structures helps children abstract the essential information from a text. Knowledge of text structure and the tools to identify them simplifies the cognitive load for the reader. It enables the reader to pay attention to details and to see the relationship among ideas that serve as a scaffold for remembering (Slater \& Graves, 1989).

Learning strategies for reading informational text with its genre specific structure is an essential component of information literacy and could serve as a vehicle for the introduction of information literacy to both teachers and students. In a national survey school librarians reported that only thirty percent of teachers and eighteen percent of students knew what the skills of information literacy were (Whelan, 2003). Smith (2001) in an analysis of school libraries identified two features at the middle school level that lead to higher achievement on a reading tests; the teacher-librarians' selection of material for instructional units, and the teaching of information literacy skills to students. While the teaching of traditional information literacy skills, such as the use of an index is essential; many of the difficulties that children encounter in carrying out typical information literacy tasks can be attributed to poor comprehension skills. The stumbling blocks in tasks such as locating and processing information in order to write a report are frequently not due to difficulty with information literacy skills narrowly defined but because of weak reading comprehension. They can locate information and perhaps select it but have difficulty with processing it. Students can use the search engine and have downloaded the information but they neither understand what it means nor can they apply the knowledge to create new documents thus the ubiquitous cut and paste "research" reports.

\section{Instruction}

Comprehension instruction with either narrative or informational text is infrequent in clementary classrooms (Armbruster, Armstrong, Wise, Janisch \& Meyer, 1991; Neilson, Rennic \& Connell, 1982; Pressley, 2002). The focus of instruction has been on the aesthetic and motivational aspects of reading, creating a rich literary environment, encouraging a response to literature and engaging students in authentic writing (Atwell, 1998; Langer, 1994). Explicit instruction in reading is less likely to occur after grade three, a common assumption being that learning to read has been accomplished by then. Teachers shift the focus of their language arts programme from teaching reading to having children use reading to respond to literature and learn in the content areas. However, learning to decode and developing fluency, the focus of primary reading instruction is not all that needs to be learned about reading. Language arts instruction after grade three should emphasise vocabulary and comprehension strategies.

Arising from research that describes the key processes used by expert adult readers (Pressley \& Afferbach, 1995) the 1980s saw a number of instructional studies for improving comprehension. Expert readers understand the role of text structure in comprehension, they can locate the main idea in a text, summarize the text, they actively self-question while reading and self-monitor their comprehension (Duke \& Pearson, 2002; Pressley, 2000). Much of this research explored the effect of individual strategies on comprehension, for example, the use of self-questioning. Two approaches to comprehension instruction were developed. Palinscar and Brown (1984) sought to teach in a naturalistic manner several components of effective comprehension combining them in an approach known as reciprocal teaching. The other major initiative was that of Rochler and Duffy (1984) in an approach known as direct 
explanation, in which the teacher explains the use of strategies and models the reasoning and mental processes through a think-aloud process.

Pressley and Wharton-MacDonald (1997) note that due to the recent emphasis on beginning reading, research on reading comprehension and strategy instruction has as received less attention since the eighties. Pressley (2000) calls for a renewed emphasis on comprehension instruction, arguing for the need to explicitly teach strategies for comprehension at the elementary school level.

The National Reading Panel's report (2000) through its critical review of 481 studies of reading comprehension concludes that there is sufficient evidence that the use of some comprehension strategies can have an impact upon student performance to merit their inclusion in an instructional intervention. Eight different strategies were identified that improve readers' comprehension, they are:

- comprehension monitoring, where readers learn how to be aware of their understanding of the material

- co-operative learning, where readers learn the reading strategies together in small groups

- the use of graphic, semantic organisers and story maps made by readers

- question answering, where readers answer questions posed by the teacher and receive immediate feedback

- question generation, where readers ask themselves questions about various aspects of the text

- story structure, where readers are taught to use the structure of the story as a means of helping to recall story content in order to answer questions about what they have read

- summarisation, where readers are taught to integrate ideas and generalise from text information

- multiple strategy instruction, where a number of strategies are used concurrently.

The most effective approach was judged to be multiple strategy instruction, which combined several strategies to enable the reader to derive meaning from a text.

\section{Struggling readers}

Many children who were reading adequately in the primary grades encounter difficulty in the intermediate grades. They lack the skills necessary for dealing with increasing conceptually complex text (Chall, Jacobs \& Baldwin, 1990). The difficulty lies in the increased conceptual load found in texts, requiring greater prior knowledge and an academic vocabulary. Low-income children are at particular risk, as their major source of prior knowledge and academic vocabulary is from exposure to informational text in school (Chall, Jacobs \& Baldwin, 1990).

World-wide, boys perform more poorly than girls on literacy measures (Shicl \& Cosgrove, 2002; TIMSS/PIRLS, 2001). A contributing cause may be the lack of materials that boys prefer in school and classroom libraries (Doiron, 2003). In general, boys prefer 
informational texts (Langerman, 1990; Worthy, Mooreman \& Turner 1999), which are less frequently used in instruction. In response the Minister of Education in the United Kingdom has recommended that schools increase the use of informational text (Barrs, 2000).

\section{Instructional approach}

Strategy instruction enhances children's reading comprehension (Pressley, 2000; Pressley, 2002; Pressley \& Wharton-MacDonald, 1997; Rosenshine \& Meister, 1994) and fosters active engagement in learning (Mier, 1984). Drawing upon the research the instructional approach used in this study-collaborative strategy instruction- incorporates aspects of reciprocal teaching and direct explanation with an effort to engage in the features of real discussions as described by Alvermann, Dillion \& O' Brien (1987). It is an instance of the multiple strategy instruction as described by the National Reading Panel.

It is unique in the emphasis it places upon collaboration amongst students and the online accessing and use of strategies. Strategies are not taught outside of the context of real reading or in any pre-determined order. They are modelled as the need arises in response to a problem with the text. This is in contrast to how strategies are frequently taught and is the manner in which expert readers use strategies. Strategies are only explicitly brought to consciousness and applied deliberately when comprehension breaks down; normally an expert reader's attentional resources are directed at comprehension.

Students, in small groups, read aloud from informational text, the teacher models how to set goals for reading, to self-monitor for comprehension, question the text, and to summarise after reading a section of text. Teachers are urged to try and place the responsibility for solving reading problems with the students. It can be a challenge for a teacher to allow the student to struggle to arrive at a solution. The other members of the group are encouraged to offer strategies to the reader if help is requested. The teacher models or provides a suggestion for solving the reading problem only once the student and group have tried to solve it for themselves.

Summarisation plays a key role in monitoring comprehension (Pressley, Johnson, Symons, McGoldrick \& Kurita, 1989). Summarisation requires the active processing that is the foundation comprehension. Typical comprehension questions can be answered by a search and find strategy, where the student looks for the sentence containing the words of the question and then repeats the sentence. Repeating the author's words does not require the processing and transformation of knowledge that is essential for understanding to occur. Comprehension can only be attributed when a reader can distil and put in his own words the ideas from a text.

\section{Texts}

Informational text was used in this study to increase students' world knowledge, academic vocabulary and to appeal to boys. Short one-page texts on a variety of topics related to social studies and science were prepared. For struggling readers a one-page text is less daunting and allows a text to be read within one session, thereby sustaining students' interest. A number of related texts were read, e.g., ancient Egypt, but each text was complete in itself. The primary goal was teaching students to be strategic readers of informational text, conceptual growth was a secondary goal and consequently although illustrations may 
enhance students' learning from text they were deliberately excluded. The focus of the sessions was on becoming a better reader and the measure of that was being able to understand the text by putting it in one"s own words.

\section{Methodology}

Two grade $4 / 5$ classes in the same school participated, an experimental and a control class. The teacher of the experimental class and the teacher-librarian were provided with training in the instructional approach-collaborative strategy instruction and the use of informational texts in reading instruction through a two-hour instructional workshop.

The teacher-librarian was recruited to be one of the teachers in the instructional intervention. She participated as the study fitted with one of her goals: to expand the library programme beyond literature activities. The school could be characterized as having had a literature-based approach to literacy and this was reflected in the library programme.

For language arts both classes had been using a literature-based approach in which students independently read novels and wrote in response journals. The school, as a whole, had a silent reading time for the first 10 minutes of the school day. Strategies for reading informational text were not part of the instruction in either participating class and the use of informational text was limited.

The school was located in the inner city of a large metropolitan city and drew from a population of First Nations and refugee families. It was considered by the administrating Board to be one of its neediest elementary schools.

\section{Participants}

The experimental class had 27 pupils, 10 boys, and 17 girls (five students were very recent immigrants and were withdrawn for ESL support during the reading period and were therefore not tested), three children were absent for one of the testing periods. Of the total of 19 participants, four were grade four students, 15 were grade five students.

The control class had 26 students, 14 boys and 12 girls (four students were withdrawn from the classroom for ESL support and were not tested), five students were away during one of the testing periods. All of 17 participants were grade five students.

Among the students tested in both classes were a number of children who had received only one to two years of schooling in English.

\section{Procedure}

Students were tested with the comprehension sub-test of the Stanford Diagnostic Reading Test, Green Level, in February and in June. This level is intended for the end of grade 3 and the first half of grade 4 . It was selected the basis of advice from the classroom teacher as many of the students had difficulty with most academic tasks and it was judged that using a grade level test would be too discouraging for the children. 
Once a week the experimental class was split in half and the teacher and the teacherlibrarian each separately, taught a group of approximately 8-10 students for 40 minutes using the instructional approach. Students participated in ten of these sessions from February to May. The students in the control class continued to receive the regular instructional programme from the classroom teacher.

\section{Results}

The comprehension scores of the experimental class were compared to the control class using a $t$ test. As shown in Table 1 below, there was no significant difference was evident between the two classes the pre-test. There was a significant difference between the two classes on the post-test. The comprehension scores for experimental class had improved more than those achieved by the control class.

Table 1: Group Differences on Comprehension Measure

Experimental (A) Control (B)

\begin{tabular}{llllll} 
& & & & & \\
& $M$ & SD & M & SD & 1 \\
\hline Pre-test & 32.89 & 6.1 & 32.35 & 7.9 & 0.23 \\
Post-test & 37.73 & 3.6 & 34.17 & 5.7 & $2.19^{*}$ \\
* $<<.05$ & & & & &
\end{tabular}

\section{Discussion}

As this was a very short study with limitations, caution is needed in generalising. However, the reading comprehension scores of struggling grade 4 and 5 students who participated in the instruction- collaborative strategy instruction-improved. It is encouraging that a limited intervention of ten sessions had an impact on the students' reading performance.

Engaging in discussion with the students around informational text revealed to the teacher of the intervention class that the ehildren often did not understand the text or much of the vocabulary, although they could read it aloud correctly and respond adequately to recitation type comprehension questions. She was surprised that in many instances, when students had to summarize the meaning of a text in their own words, they were unable to do so.

Although not evaluated, one of the underlying goals of the study was to influence the practice of classroom teachers, increasing the amount of informational text used and encouraging a more instructional approach to reading at the intermediate level.

It is interesting to note that for several years the school had instituted a school wide programme of Feuerstein's "Instrumental Enrichment" (FIE) to address the students" difficulty with learning. As noted by Savell (1986) this programme is successful when it is 
taught in conjunction with subject matter. However the school taught it as a separate programme. Perhaps one of the benefits of the instructional intervention for students participating in this study was that cognitive strategies such as self-monitoring, selfquestioning, intentional goal setting, which are features of FIE, were embedded within accomplishing the purposeful task of understanding an informational text.

The informal comments made by the teacher of the experimental group suggested that, as a response to the new knowledge about her students and their reading, she was more aware of the need to instruct and felt she now had a way of doing so. In order to teach comprehension strategies teachers need both knowledge of the content presented in the text, knowledge of the use of strategies themselves and how to model strategy use to students. Through participating in the intervention the teacher had developed some of this knowledge for reading instruction. The teacher-librarian reported that she had greater insight into reading comprehension instruction and the needs of intermediate age children. She felt that participating in an instructional role was a step toward reorienting the focus of the library programme.

Teacher-librarians serve as literacy leaders in their schools, through their knowledge of resources, curriculum, technology and information literacy skills. The library programme can influence student academic achievement (Lance, 2002; Todd, Kuhlthau \& OLEMA, 2003). Elementary school teachers are primarily concerned with children's mastery of reading and in particular their comprehension. As discussed earlier, many are not aware of information literacy or of the role of information texts in teaching. Most feel they lack sufficient time to adequately teach reading comprehension due to the many levels of reading ability found within a class.

I suggest that it would be worthwhile for teacher-librarians to consider collaborating with classroom teachers to incorporate some instruction in reading comprehension as a way to strengthen their information literacy instruction. Doing so would directly help children and would be welcomed by teachers, as it would enable them to provide small group instruction in reading comprehension for a period of time. It could also serve to build that sought after collaborative relationship with teachers, as it directly connects with their concerns. Such a component need not involve extensive lessons but can be adapted to fit the time constraints of the particular library programme, perhaps addressing a single strategy. If there were time for only one strategy then summarisation or question generation would be most productive.

Comprehension strategies for active reading could be consider a missing element in information literacy instruction, incorporating these would enable students to better utilise the other components of information literacy that they have learned.

\section{References}

Alvermann, D. E.., Dillion, D. R. \& O’Brien, D. (3. (1987). Using discussion to promote reculing comprehension. Newark, DE: International Reading Association.

Armbruster, B. B., Anderson, T.H., Armstrong, J. D., Wise, M. A.. Janisch, ('. \& Meyer, L.A. (|99)|). Reading and questioning in content area lessons. Journal of Reading Behonior: 23. 35-59.

Atwell. N. (1998). In the middle: New understandings about writing, reading and learning. Portsmount, NH: Heinemann.

Barrs. M. (2000). Gendered literacy? Language Arts, 77, 287-23.

Beck, I.. \& McKeown, M. (1991). (onditions of vocabulary acequisition. In R. Barr. M. L. Kamil. P. D). Mosenthal, \& P. D. Pearson (Eds.), /londhosk of reading resededh. (Vol. II, pp. 789-814). New York: Longmant. 
Beck, I., McKeown. M. (j., \& Kucan, L. (2002). Bringing urords to life. New York: (iuilford Press.

Bruner, J. (1986). Achal minds, possible worlds. Cambridge MA: Harvard University Press.

Chall, J. S., Jacobs, V. A., \& Baldwin, L. E. (1990). The receding crisis: Why poor children full he hind. (ambridge, MA: Harvard University Press.

(unningham, A. \& Stanovitch. K. (1997). Early reading acquisition and its relation to reading experience and ability 10 years later. Dovelopmental Psichologer, 33.934-945.

Doiron, R. (2003). Boy books, (jirl books: Should we re-organise our school library collections:? Teacher Librarian, 30, 3, 14-16.

Duke. N. (2000)). 3.6 minutes per day: The scarcity of informational texts in first grade. Reading Research Qlicurter/l); 35, 202-224.

Duke, N.K.. Bemnett-Armistead, V. S.. \& Roberts, E. M. (2003). Filling the great void. American Educter, 27. $30-35$.

Duke. N.. \& Pearson. P. D. (2002), Effective practices for developing reading comprehension. In A.t.. Farstrup.

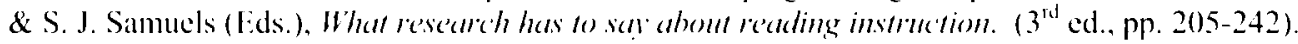
Newark. DE: International Reading Association.

Durkin, D. (1993). Teaching them to read (6 $6^{\text {th }}$ ed.). Boston: Allyn \& Bacon.

Ericsson. K. A.. \& (harness, N. (1994). Expert performance: Its structure and aceuisition. dmeric'an P.spchologist, 46, 725-747

Graves. M.. \& Watts-Taffe. S. (2002). The place of word consciousness in a research-balsed vocabulary program. In AE. Farstrup, \& S. J. Samuels (Eds), What resectrch has to sall ahout reading instruction. (3 $3^{\text {'s }}$. ed. pp. 140-165). Newark. DI: International Reading Association.

Gracsser, A., (jolding. J. M., and Long. D. L. (1991). Narrative representation and comprehension. In R. Barr, M. L. Kannil. P. D. Mosenthal, \& P. D. Pearson (Eds.). Handlhosk of reading resecarch. (Vol. II. pp. 17 I205). New York: longman.

Harris. T.. \& Hodges. R. F. (1995). The literacy dictionemy: the verabulary of receding and writing. Newark. DE: International Reading Association.

Ilirsch, L. D. Ir. (2003). Reading comprehension requires knowledge of words and the world. Americen Edecutor, 27, 10-29.

Lance, K. (. (2002). Proof of the power: Recent research on the impact of school library media programs on the academic achievement of U. S. public school students. I:RIC digest. ERIC C'learinghouse on Information and Terdmologg.

Langer, J. (1994). A response-based approach to reading literature. Language . Arts, 71, $203-11$.

Langerman. D. (1990). Books \& boys: (iender preferences and book selection. Sihool Lihremy. Aoumal. 36. 132136.

Medo, M. A.. \& Ryder. R. J. (1993). The effects of vocabulary instruction on readers" ability to make causal connections. Reseling Resectich and lnstruction, 3.3. 2 ,119-134.

Mier. M. (1994). (omprehension monitoring in the elementary school. Reading Teather, 37. 770 ()-774.

Moravesik, J. E., \& Kintsch, W. (1993). Writing ability, reading skills, and domain knowledge as factors in text comprehension. Camadian . onunal of Experimental Psicholegy: 47, 360)-374.

Nagy.W. E., \& Scott, J. (2000). Vocabulary processes. In M.I. Kamil, P. B. Mosenthal, P. D. Pearson \& R. Barr (Eds.), /landhosk of reading research (Vol. 3, pp.269-284). Mahwah, NJ: Erlbaum.

National Reading Pancl. (2000). Teaching children to read: An evidence-based assessment of the scientific research litcrature on reading and its implications for reading instruction. Reports of the subgroups Washington. DC: National Institute of Child Health and Human Development.

Neilson. A. R., Rennic, B., \& Connell, B. J. (1982). Allocition of instructional tince to reading comprehension and study skills in intermediate social studies classrooms. In J. A. Niles \& L. A. Harris (Eds.). No'll inquires in reading researdh and instruction: thirly-first gearbont of the National Reading Conference.(pp. 81-84). Rochester. NY: National Reading Conference.

Palinscar, A. S., \& Brown. A. L. (1984). Reciprocal teaching of comprehension fostering and monitoring activities. Cognition and Instration, I, 117-175.

Pressley, M. (2000). What should reading comprehension instruction be instruction of?' In M.I. Kamil, P. B. Mosenthal, P. D. Pearson, \& R. Barr (Eds.). Hemdlesek of reeding resecurch (Vol. III, pp.545-561). Mahwah. NJ: lirlbaum.

Pressley, M. (2002). Metacognition and self-regulated comprehension. In A.I. Farstrup, \& S. J. Samuels (Eds.). What research has to sal about reading instruction (3. ${ }^{\text {thd }}$. ed. pp. 291-309). Newark. DE. International Reading Association.

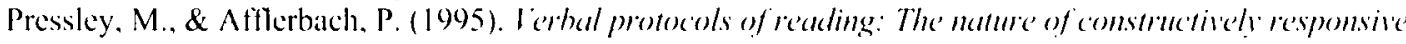
reading. Hillsdale, $\mathrm{NJ}$ : Erlbaum.

Pressley, M., Johnson, C.J., Symons, S., Mc(joldrick, J.A., \& Kurita, J. A. (1989). Strategies that improve children's memory and comprehension of what is read. Elementary Sichool Journal, 89, 3-32. 
Pressley, M., \& Wharton-MacDonald, R. (1997). Skilled comprehension \& its development through instruction. School Psichology Revicis, 26. 3. 448-467.

Rochler, L. R., \& Duffy, (i.(i (1984). Direct explanttion of comprehension processes. In (i. (i. Duffy, L.R. Rochler \& J. Mason (Eds.). (omprehension instruction: Perspectives and suggestions (pp.265-280). New York, NY: Longman.

Rosenshine. B.. \& Meister, (. (1994). Reciprocal teaching: A review of the research. Revicu of fiducational Research $64.479-530$.

Rosenblatt. L M. (1978). The reader, the text, the pem. Carbondale:Southern Illinois University Press

Savell, J. (1986). Empirical status of Feuerstein"s "Instrumental Enrichment" FII technique as a method of teaching thinking skills. Revicur of Edhrational Research, 56, 381-409).

Shiel, (i. \& Cosgrove, J. (2002), International assessments of reading literacy. Reading Teacher, 55, 690-692.

Shymansky, J. A.. Yore, L.D., \& Good. R. (1991). Elementary school teachers' belief's and pereeptions of" elementary school science, science reading, science textbooks and supportive instructional factors.

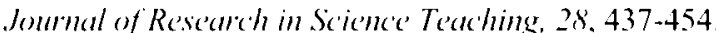

Slater, W. H., \& (iraves, M. F. (1989). Research on expository text. Implications for teachers. In K. D. Muth (Ed.). Childeen s comprehension of kexy (pp. 140-160). Newark DE: Intermational Reading Association.

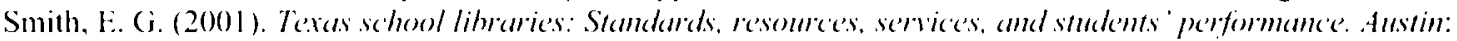
Texas State Library and Archives Commission. Retrieved October 19. 2003. from hup:/www.tsl.state.tx.us/d/pubs/schlibsurvey/survey

TIMSS/PIRLS (2001). International Association for the Evaluation of Educational Achievement, Retrieved October 19,2003 from http:/timss.be.edu/pirls200)i/PIRLS2001_news.html

Todd, R. J.. Kuhlthau. (.C.. \& OELMA. (2003). Student learning through ()hio school libraries. Retrieved March 24, 2004 from butp: www.oelma.org studentlearning.htm

Trabasso. T. (1994). The power of the narrative. In F. Lehr \& J. Osborn (Eds.), Reading, langlage, and literace: Instruction for the trenty-first century (pp. 187-200). Hillsdale, NJ: Lirlbaum

Van den Brock, P., \& Kremer, K. F. (2000). The mind in action: what in means to comprehend during reading In B. Taylor, M. Graves, \& P. van den Brock (Eds.), Reeding for meaning: Fostering comprehe'nsion in the middle grades (pp. 1-31). New York: Teachers (ollege Press.

Walsh, K. (2003). Basel readers: The lost opportunity to build the knowledge that propels comprehension. American Educator. 27, 1, 24-27.

Whelan, D. L. (2003). Why isn't information literacy catching on'? Si hool Lihrary Jommal Retrieved October 12, 2003 hutp: sli.reviewsmews.com/index.asp?'layout articleArchivedarticleid ( $\mathrm{A} 318993$

Worthy, J. Moorman, M., \& Turner, M. (1999). What Johnny likes to read is hard to tind in school. Reedeling Resecuch (murkerly, 34, 1, 12-27.

\section{Author note}

Flizabeth A. Lee is an Assistant Professor in Language and Literacy. Faculty of Lducation Queen's University, Kingston. Canada. She teaches graduate and teacher education courses in reading and language arts. Her research interests are literacy instruction in elementary and secondary schools, particularly for struggling students, information literacy and adolesent literacy. 